\title{
Humic Acid Reduces the Available Cadmium, Copper, Lead, and Zinc in Soil and Their Uptake by Tobacco
}

\author{
Qun Rong ${ }^{1,2}$, Kai Zhong ${ }^{2}$, He Huang ${ }^{1,2}$, Chuanzhang $\mathrm{Li}^{1,3}$, Chaolan Zhang ${ }^{1,2, *}$ and \\ Xinyu Nong ${ }^{2}$ \\ 1 College of Life Science and Technology GuangXi University, Nanning 530004, China; \\ rongqun216229@163.com (Q.R.); River_63@163.com (H.H.); lichuanzhang1985@163.com (C.L.) \\ 2 College of Resources, Environment and Materials GuangXi University, Nanning 530004, China; \\ chunghoi94@hotmail.com (K.Z.); Nongxy123@163.com (X.N.) \\ 3 Guangxi Zhuang Autonomous Region Environmental Monitoring Central Station, Nanning 530004, China \\ * Correspondence: zhangcl@gxu.edu.cn
}

Received: 25 November 2019; Accepted: 25 January 2020; Published: 6 February 2020

check for updates

\begin{abstract}
Tobacco (Nicotiana tabacum L.) is a crop that is able to accumulate metals. In this study, humic acid was selected as a $\mathrm{Cd}, \mathrm{Cu}, \mathrm{Pb}$, and $\mathrm{Zn}$ passivator, and added to calcareous field soil in amounts of $6.4,10.3$, and $14.8 \mathrm{~kg} \cdot \mathrm{ha}^{-1}$. Its impact on the soil fractions of the metals in the soil was extracted by the Community Bureau of Reference (BCR) sequential extraction method, and their accumulation of the metals in tobacco leaves was investigated. Application of $14.8 \mathrm{~kg} \cdot \mathrm{ha}^{-1} \mathrm{humic}^{-}$ acid decreased the DTPA-extracted concentrations of $\mathrm{Pb}, \mathrm{Cd}, \mathrm{Zn}$, and $\mathrm{Cu}$ by $39 \%, 37 \%$, 29\%, and 18\%, respectively, as compared with untreated soil. The fractions of $\mathrm{Cd}, \mathrm{Pb}, \mathrm{Cu}$, and $\mathrm{Zn}$ in soil were extracted by the BCR sequential extraction method, and the relationship between the difference metal fractions in the soil and the metal contents in the plant materials were analyzed. The exchangeable fractions of $\mathrm{Cd}, \mathrm{Pb}, \mathrm{Cu}$, and $\mathrm{Zn}$ and the reducible fractions of $\mathrm{Pb}$ and $\mathrm{Cu}$ are the main bioavailable fractions. Additionally, the reducible fractions of $\mathrm{Cd}$ and $\mathrm{Zn}$, the oxidizable fractions of $\mathrm{Pb}, \mathrm{Cu}$, and $\mathrm{Zn}$, and all residual fractions of metals were nonbioavailable fractions in the soil. The soils were treated with humic acid (HA) to shift bioavailable metals to stable phases that were less bioavailable. The available $\mathrm{Cd}, \mathrm{Pb}, \mathrm{Cu}$, and $\mathrm{Zn}$ were strongly retained in the soil after the application of humic acid, which decreased the uptake in tobacco in the upper, middle, and lower leaves.
\end{abstract}

Keywords: humic acid application; metal; bioavailable metal fraction; tobacco leaf

\section{Introduction}

Metal pollution in soils is a serious environmental problem with potentially harmful consequences for agriculture and human health. Modern agricultural practices and industrial activities have resulted in $\mathrm{Cd}, \mathrm{Cu}, \mathrm{Pb}$, and $\mathrm{Zn}$ accumulation in soils [1]. Metals occur in soil naturally and their concentrations can differ due to the soil type. [2]. Research has shown that the accumulation of $\mathrm{Cu}, \mathrm{Cd}, \mathrm{Zn}, \mathrm{Hg}$, and $\mathrm{Pb}$, and especially $\mathrm{Cd}$ in soils were enhanced by geological background and carbonate rock weathering $[3,4]$. The long-term use of phosphate fertilizers that contain these metals and the application of contaminated sewage sludge can further enrich agricultural soils with metals [5]. Because these trace elements can be found at relatively high concentrations in crops, their presence in plants is of concern for humans [6]. Hence, there is a need to either remove them from the environment or to avoid their uptake by crop plants that are consumed by humans.

Tobacco has the potential to accumulate $\mathrm{Cd}$ and $\mathrm{Pb}$ from contaminated soil [7]. Excessive $\mathrm{Cd}$ taken up by tobacco inhibits the absorption of N, P, and K, reducing the biomass of shoot and root [8], while $\mathrm{Pb}$ mainly influences seed germination and photosynthesis [9]. In contrast, $\mathrm{Cu}$ and $\mathrm{Zn}$, which are 
essential mineral elements for plant growth, are crucial for maintaining chloroplast structure, enzyme activity, tobacco aroma and growth [10]. Research has shown that soil with 2.0 to $4.8 \mathrm{mg} / \mathrm{kg} \mathrm{Zn} \mathrm{benefits}$ tobacco growth, making it possible to increase production and quality, and accelerate the uptake of nutrients [11]. However, tobacco can be poisoned by high concentrations ( $>9.8 \mathrm{mg} / \mathrm{kg}$ ) of $\mathrm{Zn}$ in the soil $[12,13]$. It is known that heavy metals in tobacco get into the human body from the smoke that gets through the lungs of people who smoke. Indeed, tobacco is considered a major source of toxic metals in human blood and various organs [14]. Unfortunately, heavy metals in tobacco have not aroused widespread public awareness, and administration related to the content of heavy metals in tobacco is still lacking.

Total metal concentrations alone cannot evaluate the metal's mobility, bioavailability, and environmental impact sufficiently [15]. The Community Bureau of Reference (BCR) sequential extraction method is widely used to determine the binding forms and the mobilities of metals in soils. Furthermore, diethylene triamine pentaacetate acid (DTPA) extracted metals have been reported to have better correlations between soil metal content and crop tissue content $[16,17]$. In general, $\mathrm{Pb}, \mathrm{Cd}$, and $\mathrm{Zn}$ are preferentially taken up by tobacco due to their potential bioavailability $[18,19]$. In comparison to the total metal concentrations, the available or exchangeable and reducible fractions are highly correlated [20]. Some studies have shown that the available, exchangeable, and reducible fractions mainly determine the mobility and bioavailability [21] or phytotoxicity [22] of, for example, $\mathrm{Cd}, \mathrm{Cu}, \mathrm{Pb}$, and $\mathrm{Zn}$ in soils. Passivation methods, by transfer metals to stable phases, have been widely used in the remediation of metal-contaminated soils [23]. Various methods and techniques have been used for passivation of $\mathrm{Cd}, \mathrm{Pb}, \mathrm{Cu}$, and $\mathrm{Zn}$, but the application of humic acid (HA) is one of the most promising $[24,25]$. HA has a high complexation capacity for these metals as it contains carboxylic and phenolic groups as complexation sites, which can reduce the bioavailability and mobility of metals [26-29]. Therefore, quantifying the available, exchangeable, and reducible fractions after HA application is necessary to assess metal mobility.

The application of humic acid to stabilize (i.e., immobilize) metal ions, especially cations, in soil has been widely used $[21,24,25]$. HA amendments have been proven to be effective to improve soil functions, and especially to enhance the ability of anti-acidification and fertility [24,30,31], allowing for the establishment of a plant cover. However, most of these experiments were conducted in the laboratory, and the effects of HA on heavy metal uptake by tobacco in the field have not yet been evaluated.

In this study, HA was applied in a field experiment with tobacco, and the available and chemical fraction contents of $\mathrm{Cu}, \mathrm{Zn}, \mathrm{Cd}$, and $\mathrm{Pb}$ and their accumulation in different parts of tobacco leaves were determined. The aims of this study were as follows: (1) To illustrate the passivation effects of HA at different dosages in a field experiment and (2) to determine the effects of HA-treated soil on the uptake of these metals into tobacco leaves. The findings could help reducing the risk of metal contamination in soil and improve the quality of tobacco.

\section{Materials and Methods}

\subsection{Soil, Plant, and Humic Acid Characterization}

The field experiment was carried out in Luo Cheng County which is located in the northern part of the Zhuang Nationality Autonomous Region, Guangxi. The soil was classified as a typical calcareous soil. Its total $\mathrm{Cd}$ content is significantly higher than that given in the Chinese soil environmental quality standards, while the total $\mathrm{Pb}, \mathrm{Cu}$, and $\mathrm{Zn}$ content are lower than the standard value. The basic soil characteristics are shown in Table 1. 
Table 1. Soil characteristics and Chinese soil environmental quality standards (total concentration in $\left.\mathrm{mg} \cdot \mathrm{kg}^{-1}\right)$.

\begin{tabular}{|c|c|c|c|c|c|c|c|c|c|c|c|c|c|}
\hline \multirow{2}{*}{ Item } & \multirow{2}{*}{$\mathrm{pH}$} & \multirow{2}{*}{$\begin{array}{l}\text { Organic } \\
\text { Matter } \\
\text { Content }\end{array}$} & \multirow{2}{*}{$\begin{array}{l}\text { Available } \\
\text { N }\end{array}$} & \multirow{2}{*}{$\begin{array}{c}\text { Available } \\
\quad \mathbf{P}\end{array}$} & \multirow{2}{*}{$\begin{array}{c}\text { Available } \\
\text { K }\end{array}$} & \multicolumn{4}{|c|}{ Total Content } & \multicolumn{4}{|c|}{ DTPA Extracted } \\
\hline & & & & & & $\mathrm{Cd}$ & $\mathrm{Pb}$ & $\mathrm{Cu}$ & $\mathrm{Zn}$ & $\mathrm{Cd}$ & $\mathrm{Pb}$ & $\mathrm{Cu}$ & $\mathrm{Zn}$ \\
\hline Soil & 7.8 & 21 & 109 & 12 & 141 & 3.82 & 21.31 & 36.02 & 146.69 & 0.73 & 1.42 & 3.38 & 4.46 \\
\hline $\begin{array}{l}\text { Chinese } \\
\text { standard }\end{array}$ & $>7.5$ & - & - & - & - & 0.6 & 170 & 100 & 300 & - & - & - & - \\
\hline
\end{tabular}

Tobacco seeds (variety K326, Guangxi Nanning Tobacco Co., China) were germinated in pots filled with vermiculite in a greenhouse. Seedlings were transferred into the field 28 days after germination.

HA was extracted from lignite (provided by Guangxi Nanning Ruihong Energy Technology Co., China) [32], following a modified International Humic Substances Society procedure. Briefly, air-dried coal was extracted with a solution of $0.1 \mathrm{~mol} \mathrm{~L}^{-1} \mathrm{Na}_{4} \mathrm{P}_{2} \mathrm{O}_{7}$ and $0.1 \mathrm{~mol} \cdot \mathrm{L}^{-1} \mathrm{KOH}$ using a coal-to-extractant ratio of $1: 10(\mathrm{w}: \mathrm{v})$ by mechanical shaking at room temperature. Then, the mixtures were allowed to stand for $24 \mathrm{~h}$ to separate the solid residue by sedimentation and the supernatant natural deposition. The extraction was repeated three more times. The combined supernatants were acidified to a pH of 1 with $6 \mathrm{~mol} \mathrm{~L}^{-1} \mathrm{HCl}$, allowed to stand for $24 \mathrm{~h}$ to permit coagulation of $\mathrm{HA}$, and then natural deposited for $12 \mathrm{~h}$. The precipitated HA was purified by dissolution in an extraction solution, allowed to stand for $12 \mathrm{~h}$ to deposit the residue completely, and acidified again to a $\mathrm{pH}$ of 1 with $6 \mathrm{~mol} \cdot \mathrm{L}^{-1} \mathrm{HCl}$. The suspensions were allowed to stand for $24 \mathrm{~h}$ at $20 \pm 2{ }^{\circ} \mathrm{C}$, and the sediments were recovered. The purification steps were repeated three more times together. The precipitated HAs were, then, recovered with distilled water and dialyzed. When free of $\mathrm{Cl}^{-}\left(\mathrm{AgNO}_{3}\right.$ test), the $\mathrm{HAs}$ were recovered and air-dried for $24 \mathrm{~h}$ at $20 \pm 2{ }^{\circ} \mathrm{C}$.

\subsection{Experimental Design}

Each of the four experimental areas was $46.8 \mathrm{~m}^{2}(13.0 \mathrm{~m} \times 3.6 \mathrm{~m})$, and each treatment was replicated on four plots in a randomized block design. In each plot, there were three rows $1.2 \mathrm{~m}$ apart, with 26 tobacco plants per row spaced in each row $0.5 \mathrm{~m}$ apart, for a total of 78 tobacco plants per plot. For separation between the plots of different treatments, three rows of tobacco were used. The four treatments were as follows: one control without HA addition (Control), and three treatments with total amounts of dry HA of $6.4 \mathrm{~kg} \cdot \mathrm{ha}^{-1}$ (HA6.4), $10.3 \mathrm{~kg} \cdot \mathrm{ha}^{-1}$ (HA10.3), and $14.8 \mathrm{~kg} \cdot \mathrm{ha}{ }^{-1}$ (HA14.8) by application of an aqueous suspension of HA (dry HA dissolved in $100 \mathrm{~L}$ water) to the soil near the plants root, $24 \%$ of the total amount at day $30,38 \%$ at day 45 , and $38 \%$ at day 64 after transplantation. The ambient temperature in the tobacco growing area was approximately $25 / 19{ }^{\circ} \mathrm{C}$ (day/night), the photoperiod was approximately $15 \mathrm{~h}$ per day, and the relative humidity was $75 \%$. Prior to tobacco planting, basic fertilizer was applied at $30 \mathrm{~kg} \cdot \mathrm{ha}^{-1} \mathrm{~N}, 100 \mathrm{~kg} \cdot \mathrm{ha}^{-1} \mathrm{P}_{2} \mathrm{O}_{5}$, and $260 \mathrm{~kg} \cdot \mathrm{ha}^{-1}$ $\mathrm{K}_{2} \mathrm{O}$. Tobacco growth management was based on the cultural practices recommended by the Tobacco Institute in the Zhuang Nationality Autonomous Region, Guangxi.

\subsection{Sampling and Analysis}

In the spring before fertilization and in the fall after tobacco harvest, soil samples consisting of five subsamples of $1 \mathrm{~kg}$ were taken from the layer from 0 to $20 \mathrm{~cm}$ of each experimental plot, and composite samples of treatment were prepared for each plot by mixing the subsamples. The composite samples were air-dried for 7 days, removed of plant residue and stones, crushed, and passed through a $2 \mathrm{~mm}$ sieve for available metals analyses and through a $0.15 \mathrm{~mm}$ sieve for total metals analyses. The soil samples were used for determinations of the $\mathrm{pH}$ (soil to carbon dioxide-free water $=1: 2.5, \mathrm{w} / \mathrm{v}$, UB-10, Denver Instrument, U.S.), available $\mathrm{N}\left(1.0 \mathrm{~mol} \mathrm{~L}^{-1} \mathrm{NaOH}\right.$ and $\left.\mathrm{H}_{3} \mathrm{BO}_{3}\right)$, available $\mathrm{P}\left(0.5 \mathrm{~mol} \mathrm{~L}^{-1}\right.$ $\left.\mathrm{NaHCO}_{3}\right)$, and available $\mathrm{K}\left(1.0 \mathrm{~mol} \mathrm{~L}^{-1} \mathrm{NH}_{4} \mathrm{OAc}\right)$ [33]. For total metals analyses, $0.2000 \mathrm{~g}$ of soil 
was digested by $8 \mathrm{~mL}$ of $\mathrm{HNO}_{3} / \mathrm{HCl}(1 / 3, \mathrm{v} / \mathrm{v})$. The available metals contents were extracted from $5.00 \mathrm{~g}$ of soil with $20 \mathrm{~mL}$ of an aqueous solution of diethylene triamine pentaacetatic acid (DTPA) (Sinopharm Chemical Reagent Co., Shanghai, China) [34]. The soil samples were air-dried and ground to pass through a 60-mesh sieve, and then the modified BCR sequential extraction method (European Communities Bureau of Reference) was applied to measure different fractions of $\mathrm{Cd}, \mathrm{Pb}, \mathrm{Cu}$, and $\mathrm{Zn}$ in the soil as follows $[25,35]$ :

Exchangeable fraction of metals The air-dried soil samples (2 $\mathrm{g}$ dry weight) were extracted with $20 \mathrm{~mL}$ of $1 \mathrm{~mol} \mathrm{~L}^{-1} \mathrm{MgCl}_{2}\left(\mathrm{pH}=7.0\right.$ ) in Teflon centrifuge tubes for $1 \mathrm{~h}$ at $25 \pm 1{ }^{\circ} \mathrm{C}$ with continuous agitation. The suspension was then centrifuged ( $5000 \mathrm{~g}$ for $5 \mathrm{~min}$ ). The supernatant liquid was filtered through $0.45 \mu \mathrm{m}$ filter paper and stored at $4{ }^{\circ} \mathrm{C}$ prior to analysis.

Reducible fraction The residue from the exchangeable fraction was extracted with $20 \mathrm{~mL}$ of $0.04 \mathrm{~mol} \cdot \mathrm{L}^{-1} \mathrm{NH}_{2} \mathrm{OH} \cdot \mathrm{HCl}$ (solvent is HAc solution, Hac: water $=1: 4$ ) with a $\mathrm{pH}$ of 1.5 for $6 \mathrm{~h}$ at $25 \pm 1{ }^{\circ} \mathrm{C}$ with continuous agitation. The suspension was then centrifuged and filtered as in the first step.

Oxidizable fraction The residue from the reducible fraction was extracted with $20 \mathrm{~mL}$ of $30 \%$ $\mathrm{H}_{2} \mathrm{O}_{2}\left(\mathrm{pH}=2.0\right.$, with $\left.1 \mathrm{M} \mathrm{HNO}_{3}\right)$ for $2 \mathrm{~h}$ at $85 \pm 2{ }^{\circ} \mathrm{C}$ with occasional agitation and an additional $20 \mathrm{~mL}$ of $3.2 \mathrm{~mol} \mathrm{~L}^{-1} \mathrm{NH}_{4} \mathrm{Ac}$ for $16 \mathrm{~h}$ at $85 \pm 2{ }^{\circ} \mathrm{C}$ with continuous agitation. The suspension was centrifuged and filtered as described in the first step.

Residual fraction of metals The residue from the oxidizable fraction was removed and microwave-digested with $8 \mathrm{~mL}$ of $\mathrm{HNO}_{3}, 2 \mathrm{~mL}$ of $\mathrm{HClO}_{4}$, and $2 \mathrm{~mL}$ of $\mathrm{HF}$.

The flowers were removed when the tobacco was mature. The leaves were divided into upper, middle and lower leaves according to the different developmental stages of each plant from top to bottom at maturity. The lower leaves were the 1 st to 6 th leaves, the middle leaves were the 7 th to 12 th leaves, and the upper leaves were the 13th to 19th leaves. The leaves were collected by hand, tips and veins were removed after washing with deionized water, and the leaves were dried at $65^{\circ} \mathrm{C}$ for $48 \mathrm{~h}$ in an oven before being grounded with a crusher. The plant materials $(0.5000 \mathrm{~g})$ were microwave-digested by $8 \mathrm{~mL} \mathrm{HNO}{ }_{3} / \mathrm{H}_{2} \mathrm{O}_{2}(4 / 1, \mathrm{v} / \mathrm{v})$ in a microwave digester (Mars 6, CEM, US) at $220^{\circ} \mathrm{C}$ for $30 \mathrm{~min}$ until a clear solution about 1 to $2 \mathrm{~mL}$ was obtained. The concentrations of $\mathrm{Cu}, \mathrm{Zn}$, and $\mathrm{Pb}$ were determined by flame atomic absorption spectroscopy (ZEEnit 700P, Analytik Jena, Jena, Germany). The content of $\mathrm{Cd}$ was analyzed using graphite furnace atomic absorption spectrometry (ZEEnit 700P, Analytik Jena, Jena, Germany). During the procedure, digestion blanks and certified reference materials (GBW10044, GSB-22) were included for quality control.

\subsection{Data Processing}

The data were analyzed using analysis of variance (ANOVA). Duncan's multiple range tests were used to detect differences between means for the fixed effects at the probability levels of $p<0.05$ and $p<0.01$ (IBM SPSS Statistics 19.0). The figures were drawn with Origin Pro 8.0.

\section{Results}

\subsection{DTPA Extracted $\mathrm{Cd}, \mathrm{Pb}, \mathrm{Cu}$, and $\mathrm{Zn}$ in the Soil}

The contents of the DTPA-extracted metals contents were significantly decreased with HA treatment $(p<0.05$, Figure 1) as compared with the CK treatment. The HA10.8-amended soil presented lower concentrations of DTPA-extracted metals than the other treated soils, with DTPA-extracted Cd, $\mathrm{Pb}, \mathrm{Cu}$, and $\mathrm{Zn}$ contents reduced by $37 \%, 39 \%, 18 \%$, and $29 \%$, respectively, as compared with those in $\mathrm{CK}$. The reduction of the DTPA-extracted metal fraction was more significant for $\mathrm{Cd}$ and $\mathrm{Pb}$ than for $\mathrm{Cu}$ and $\mathrm{Zn}$. 

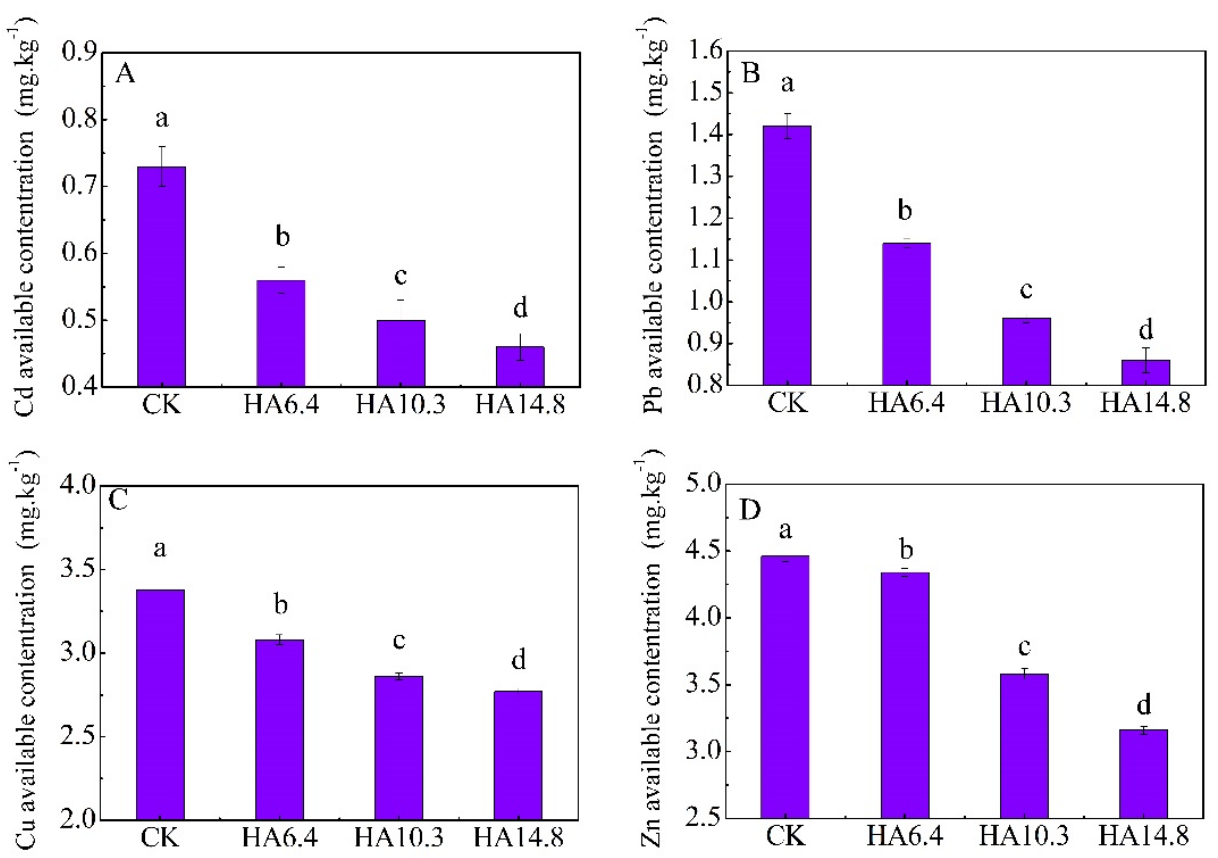

Figure 1. The DTPA-extracted $\mathrm{Cd}(\mathrm{A}), \mathrm{Pb}(\mathrm{B}), \mathrm{Cu}(\mathrm{C})$, and $\mathrm{Zn}(\mathrm{D})$ in soil after harvest of tobacco. Different lowercase letters in the same column indicate significant differences at $p<0.05$ according to Duncan's test. Bars represent standard errors $(n=4)$.

\subsection{Chemical Fractions of $\mathrm{Cd}, \mathrm{Pb}, \mathrm{Cu}$, and $\mathrm{Zn}$ in the Soil}

The modified BCR sequential extraction was applied to determine the metal fractions in the soil. The RES Cd, $\mathrm{Pb}, \mathrm{Cu}$, and $\mathrm{Zn}$ constituted the largest proportion of the total content, which exceeded $40 \%$, and $\mathrm{Zn}$ reached $65 \%$ (Figure 2). The fates and behaviors of the $\mathrm{Cd}, \mathrm{Pb}, \mathrm{Cu}$, and $\mathrm{Zn}$ fractions were different with the HA treatments. With increasing amounts of $\mathrm{HA}$, the concentrations of exchangeable fractions of $\mathrm{Cd}, \mathrm{Pb}, \mathrm{Cu}$, and $\mathrm{Zn}$, and the reduction fraction of $\mathrm{Pb}$ and $\mathrm{Cu}$ decreased with a corresponding increase of the other fractions. The oxidizable fraction is mainly the chelates of organics and metals [25], and in this study, it was clearly observed that the oxidizable fractions of $\mathrm{Pb}, \mathrm{Cu}$, and $\mathrm{Zn}$ increased with increasing HA; however, there was no significant change in the fraction of the oxidizable Cd. It is worth noting that the RESs of $\mathrm{Cd}, \mathrm{Cu}$, and $\mathrm{Zn}$ with $\mathrm{HA}$ treatment showed no significant difference as compared with the CK treatment. Overall, the soils treated with HA showed shifts of the soil metals away from exchangeable fractions to forms that are stable phases and less bioavailable. 

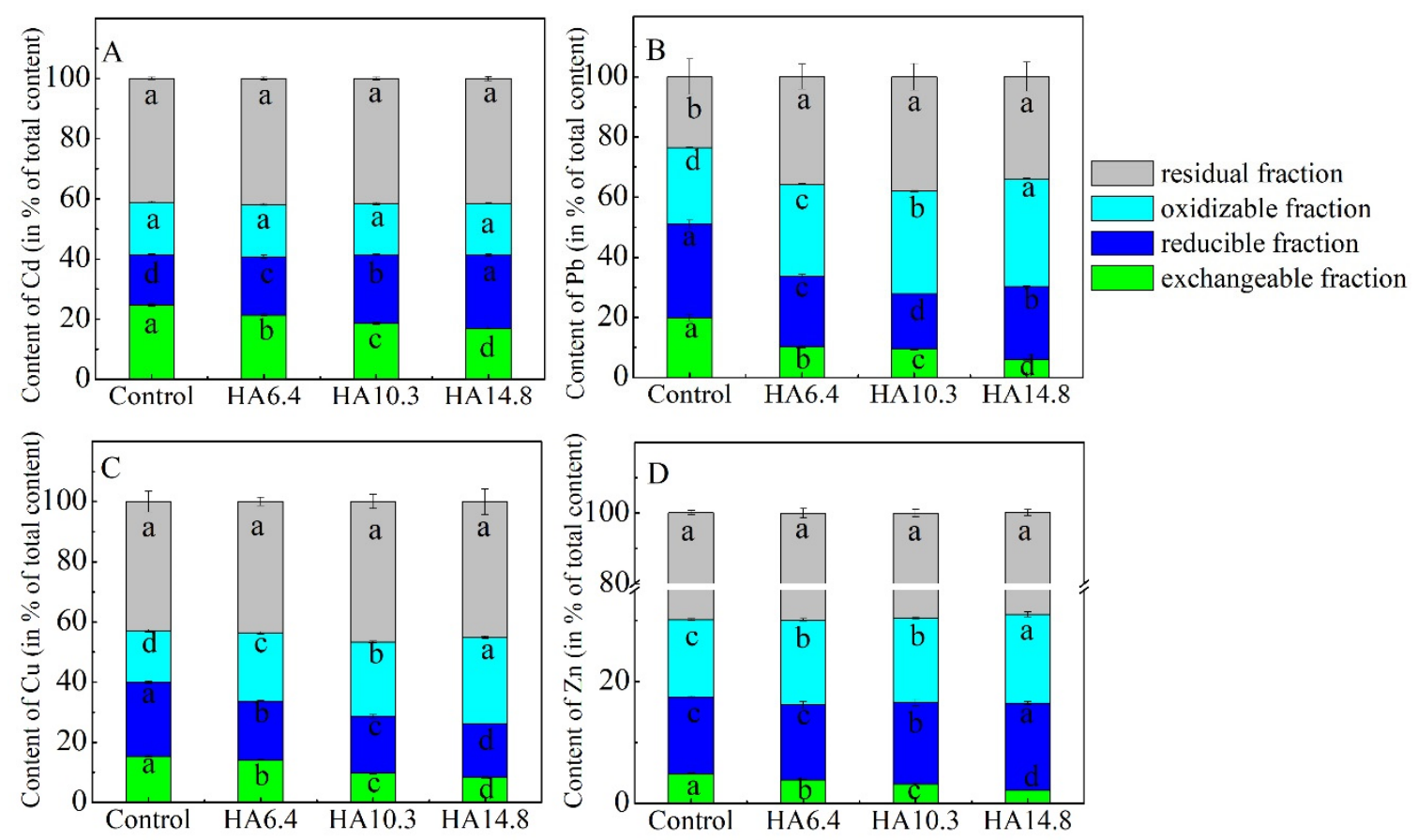

Figure 2. The chemical fractions of $\mathrm{Cd}(\mathrm{A}), \mathrm{Pb}(\mathrm{B}), \mathrm{Cu}(\mathrm{C})$, and $\mathrm{Zn}(\mathrm{D})$ in soil after harvest of tobacco. Data are means \pm SD $(n=4)$ and bars represent standard errors. Lowercase letters represent significant differences at the 0.05 level between different treatments at the same fraction.

\subsection{Metal Transport into Leaves of Tobacco of Different Ages.}

Tobacco has the ability to accumulate metals and transport them from the roots into the shoots. The contents of metals in soil and tobacco leaves were analyzed. Here "accumulation" means the concentration of a metal in the plant is higher than that in the soil. Figure 3 shows that tobacco had an accumulation effect for $\mathrm{Cd}$, while it had only an uptake effect for $\mathrm{Pb}, \mathrm{Cu}$, and $\mathrm{Zn}$. The soils treated with $\mathrm{HA}$ received a dramatic decrease in the $\mathrm{Cd}, \mathrm{Pb}, \mathrm{Cu}$, and $\mathrm{Zn}$ contents in the tobacco leaves $(p<0.05$, Figure 3), and with the HA dosage increasing, the uptake of metals in the tobacco leaves decreased. It should be noted that in the HA14.8 treatment, the Cd contents in the upper, middle, and lower parts of the leaves were reduced by $32 \%, 32 \%$, and $33 \%$, and those of $\mathrm{Pb}$ were reduced by $50 \%, 31 \%$, and $25 \%$, respectively. Additionally, the Cu contents were reduced by $15 \%, 25 \%$, and $29 \%$, and the $\mathrm{Zn}$ contents were reduced by $9 \%, 9 \%$, and $9 \%$, respectively. That is to say, the inhibit effect of $\mathrm{Cd}$ and $\mathrm{Pb}$ is much stronger than that of $\mathrm{Cu}$ and $\mathrm{Zn}$.

The distribution of metals in the tobacco leaves followed certain rules. For $\mathrm{Cd}$, the contents in the leaves exclusively followed the order of lower leaves $>$ upper leaves $>$ middle leaves; for $\mathrm{Cu}$, upper leaves $>$ middle leaves $>$ lower leaves; for $\mathrm{Zn}$, middle leaves $>$ lower leaves $>$ upper leaves. However, the $\mathrm{Pb}$ distribution was irregular. 

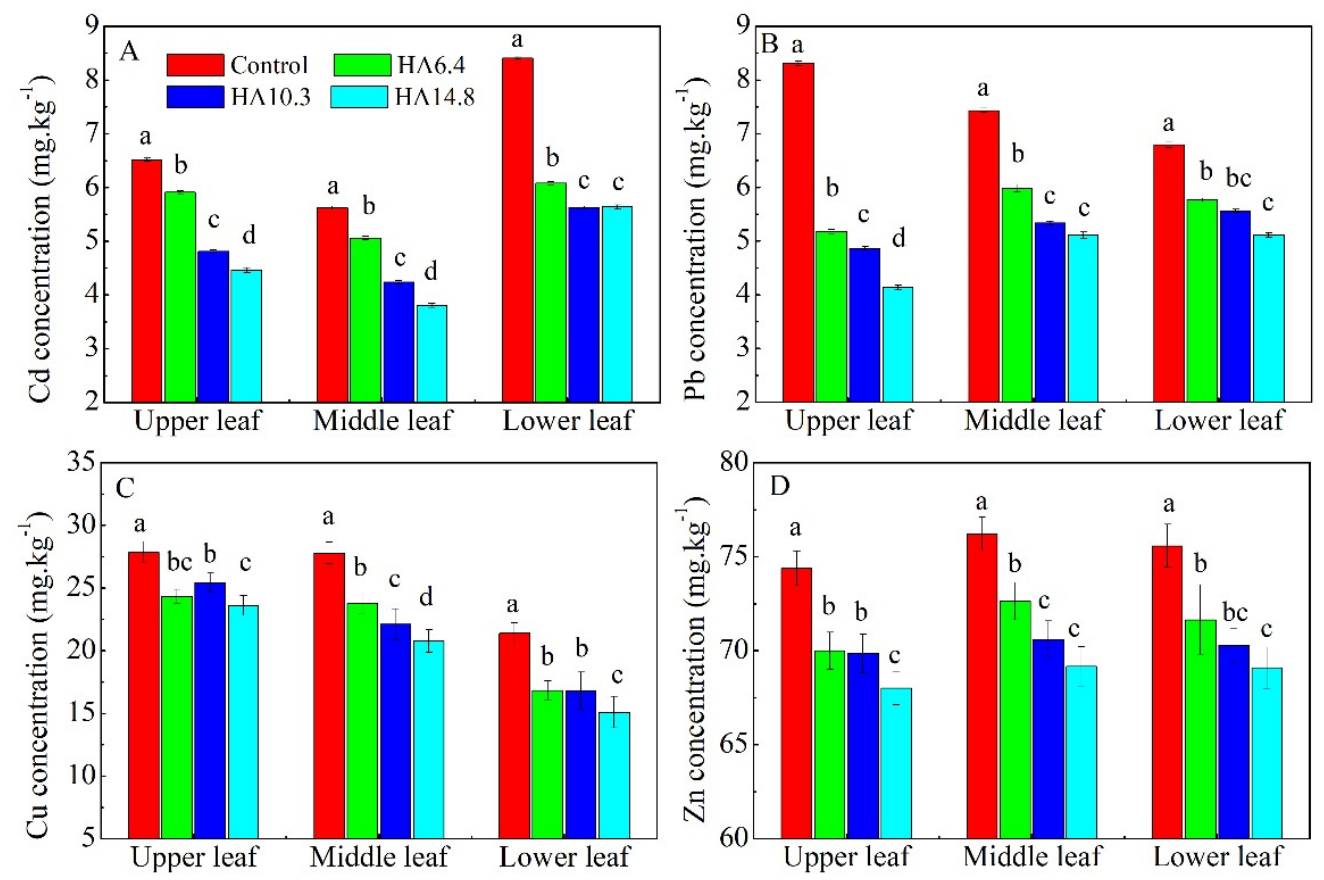

Figure 3. The contents of $\mathrm{Cd}(\mathrm{A}), \mathrm{Pb}(\mathrm{B}), \mathrm{Cu}(\mathrm{C})$, and $\mathrm{Zn}(\mathrm{D})$ in different parts of tobacco leaves. Lowercase letters indicate significant differences among $\mathrm{Cd}, \mathrm{Pb}, \mathrm{Cu}$, and $\mathrm{Zn}$ contents in the same part of the leaves $(p<0.05)$. Bars represent standard errors $(n=4)$.

\subsection{Correlations between the Fractions of Metals with the Contents in Tobacco}

The DTPA-extracted metals contents showed a positive correlation with the metal contents of tobacco leaves (Table 2). Furthermore, the relationship between the metal fractions and leaf absorption was further analyzed, and the results showed that the $\mathrm{Cd}, \mathrm{Pb}, \mathrm{Cu}$, and $\mathrm{Zn}$ exchangeable fractions and the $\mathrm{Pb}$ and $\mathrm{Cu}$ reduction fractions presented a significant positive correlation with the enrichment of metals in the leaves $(p<0.01$, Table 2), while the reduction fractions of $\mathrm{Cd}$ and $\mathrm{Zn}$ were markedly negatively correlated with leaf uptake. For the oxidizable fractions, there were negative correlations between the $\mathrm{Pb}, \mathrm{Cu}$, and $\mathrm{Zn}$ contents in leaves and the oxidizable fractions of metals in the soil; in contrast, $\mathrm{Cd}$ showed a positive (but not significant) correlation $(p<0.01$, Table 2$)$. This result is consistent with Figure 2. This finding indicates that the exchangeable fractions of $\mathrm{Cd}, \mathrm{Pb}, \mathrm{Cu}$, and $\mathrm{Zn}$ and the reduction fractions of $\mathrm{Pb}$ and $\mathrm{Cu}$ were the bioavailable fractions in the soil. Additionally, the reducible fractions of $\mathrm{Cd}$ and $\mathrm{Zn}$; the oxidizable fractions of $\mathrm{Zn}, \mathrm{Pb}$, and $\mathrm{Cu}$; and all the residual fractions were the nonbioavailable fractions.

Table 2. Pearson correlation coefficients were used to analyze the relationship between the different metal fractions in the soil and the metal content in the plant materials.

\begin{tabular}{ccccc}
\hline Item & $\mathbf{C}_{\text {leaf }}-\mathbf{C d}$ & $\mathbf{C}_{\text {leaf }}-\mathbf{P b}$ & $\mathbf{C}_{\text {leaf }}-\mathbf{C u}$ & $\mathbf{C}_{\text {leaf }}-\mathbf{Z n}$ \\
\hline DTPA-extraction & $0.955^{* *}$ & $0.972^{* *}$ & $0.895^{* *}$ & $0.830^{* *}$ \\
Exchangeable fraction & $0.985^{* *}$ & $0.993^{* *}$ & $0.754^{* *}$ & $0.928^{* *}$ \\
Reducible fraction & $-0.979^{* *}$ & $0.807^{* *}$ & $0.921^{* *}$ & $-0.677^{* *}$ \\
Oxidizable fraction & $0.416 \mathrm{~ns}$ & $-0.940^{* *}$ & $-0.939^{* *}$ & $-0.876^{* *}$ \\
Residual fraction & $-0.228 \mathrm{~ns}$ & $-0.661^{* *}$ & $-0.192 \mathrm{~ns}$ & $-0.019 \mathrm{~ns}$ \\
\hline
\end{tabular}

F-values for the available fractions of metals were determined by the accumulation and interaction of metals in tobacco; ns, nonsignificant F ratio $(p \leq 0.05) ;{ }^{* *}$ indicates that the correlation is significant at the 0.01 level and indicates a negative correlation. 


\section{Discussion}

The soil of the tobacco growing region has a typical calcareous soil, geological background and the carbonate rock weathering effect releases metals into the soil, especially $\mathrm{Cd}[3,4]$, which increases the soil metal concentration and the environmental risk. HA reduces the bioavailability of metals by strong affinity and ability of forming stable chelate with metal ions, with carboxylic groups and phenolic-OH being the dominant binding groups in HA; this effect varies by metals [26-28]. Metals have different affinities for $\mathrm{HA}$ based on their stability constants, and $\mathrm{Pb}(14.8)$ has a stronger affinity than $\mathrm{Cd}(7.8)$, $\mathrm{Cu}(13.3)$, and $\mathrm{Zn}(8.1)$ [36]. It is worth emphasizing that the binding order of metals to HA in a typical multimetal contaminated soils is $\mathrm{Pb}>\mathrm{Zn} \approx \mathrm{Cu}>\mathrm{Cd}$ [21]. The data processed by the Scatchard method has revealed two binding sites for $\mathrm{Cu}$ and $\mathrm{Pb}$ and one binding site for $\mathrm{Cd}$ and $\mathrm{Zn}$ in the sediments; thus, the complexing capacity order was $\mathrm{Pb}>\mathrm{Cu}>\mathrm{Cd}$ [37]. In this study, the reduction of available $\mathrm{Pb}$ (Figure 1, removal rate range 20\% to $39 \%$ ) in soil was higher than those of $\mathrm{Zn} \mathrm{(3 \%} \mathrm{to} 29 \%$ ), $\mathrm{Cu}$ ( $9 \%$ to $18 \%$ ), and $\mathrm{Cd}(23 \%$ to $37 \%)$. In addition, metals at low concentrations can be more effectively redistributed than those at high concentrations [38], and the fractions of metals are also critical factors affecting the removal of available metals [21,39]. In this study, the total Cd in the soil was much lower than the amounts of other metals, while its exchangeable fraction content was higher. Conversely, the $\mathrm{Pb}$ and $\mathrm{Cu}$ exchangeable fractions were less than $20 \%$, and the RES of $\mathrm{Cu}$ was up to $65 \%$ in the initial soil. Although some studies have shown that $\mathrm{Cd}$ has lower affinity for HA than $\mathrm{Cu}$ and $\mathrm{Zn}[26,40]$, based on the above analysis, the reduction of available $\mathrm{Cd}$ (removal rate range was $23 \%$ to $37 \%$ ) was more significant than that of available $\mathrm{Zn}$ and $\mathrm{Cu}$ (Figure 2 and Table 2).

Using the chemical fraction results instead of the total metal concentrations provides better insight into the distribution and binding forms of metals for a better assessment of their mobility and bioavailability [22]. According to the BCR procedure, metal in the exchangeable fraction easily migrates and transforms in the soil and is accumulated by plants. Metal in the reducible fraction is associated with amorphous Fe and Mn (hydro) oxides, and these oxides strongly sorb metals, but according to soil environmental conditions, they are possibility desorbed. The oxidizable fraction is mainly organic and metal chelate, which has low mobility. Residual metal shows stronger stability and lower leaching potential in soil [21]. Therefore, the exchangeable fraction and reduction fraction are bioavailable, relatively soluble, and easily extracted when soil properties change, and these fractions are taken up by plants, constituting a greater environmental risk than those from OXI and RES [19,41]. The majority of studies have found that the exchangeable fraction and reduction fraction can be transformed by organic amendments and converted into fractions (OXI and RES) scarcely taken up by plants [25,42] because the oxidizable fraction and residual fraction bind with HA forming a chelate. Some complex mechanisms can occur during HA and metal interactions because the HA surface is rich in functional groups (carboxylic and hydroxyl groups) that easily forming complexes with metals. Range analysis (HA additions of $6.4,10.3$, and $14.8 \mathrm{~kg} \cdot \mathrm{ha}^{-1}$ ) showed that HA was the major factor that influenced the passivation of $\mathrm{Cd}, \mathrm{Pb}, \mathrm{Cu}$, and $\mathrm{Zn}$, in all treatments (Figure 1), and the $\mathrm{Cu}$ and $\mathrm{Pb}$ exchangeable + reducible fractions were bound and rendered unavailable (Figure 2, the oxidizable + residual fraction significantly increased). Combining these results with the Pearson correlation coefficient results (Table 1) indicated that the exchangeable fractions for $\mathrm{Cd}, \mathrm{Cu}, \mathrm{Pb}$, and $\mathrm{Zn}$ and the reduction fractions for $\mathrm{Pb}$ and $\mathrm{Cu}$ were the main bioavailable metal fractions. Furthermore, the reduction fraction of $\mathrm{Cd}$; oxidizable fractions of $\mathrm{Pb}, \mathrm{Cu}$, and $\mathrm{Zn}$; and all the residual fractions were the main nonbioavailable fractions (Table 2, significant correlations of each fraction with the available metals).

The total concentration of metals has been used as an indicator to evaluate soil contamination. However, more and more researchers believe that the available fraction of metals is better when evaluating the metal uptake effect by plants [43]. Tobacco has different responses regarding the accumulation and mobility of $\mathrm{Cd}, \mathrm{Cu}, \mathrm{Pb}$, and $\mathrm{Zn}[44,45]$, and tobacco preferentially accumulates $\mathrm{Cd}$ rather than $\mathrm{Pb}$ [46]. The distribution of $\mathrm{Cd}$ in the tobacco leaves followed the order lower $>$ middle > upper [47]. Wei [48] showed that the Cd content in lower leaves was higher than that in upper and middle leaves, indicated that $\mathrm{Cd}$ was more easily accumulated than transferred in mature 
leaves. The cumulative effect of tobacco with HA treatment was significantly lower than that in the CK treatment, indicating that $\mathrm{HA}$ applied to soil could decrease $\mathrm{Pb}$ absorption in tobacco. The reason for the high contents of $\mathrm{Zn}$ and $\mathrm{Cu}$ in the leaves is that these elements are essential nutrients for tobacco plants. However, the growth and quality are negatively affected when $\mathrm{Cd}$ and $\mathrm{Pb}$ occur in excess in tobacco leaves. The distribution of $\mathrm{Cu}$ and $\mathrm{Zn}$ in the different parts of the leaves exclusively followed a certain order, but the differences were not distinct (Figure 3). According to the distribution of metals in the tobacco leaves, $\mathrm{Zn}$ absorbed more easily in the middle leaves and could be transferred to the lower and upper leaves [49]. In contrast, $\mathrm{Cu}$ uptake in tobacco is more likely to occur in immature leaves. Therefore, as compared with those of $\mathrm{Cu}$ and $\mathrm{Zn}$, the toxic effects of $\mathrm{Cd}$ and $\mathrm{Pb}$ on tobacco deserve more attention.

Research showed that China's tobacco plants have a higher concentration of heavy metal [50,51]. Thus, it is of great significance to decrease the heavy metal uptake of tobacco by application of HA. This study indicates that HA can be applied to soil contaminated by heavy metals, significantly reducing the bioavailability of heavy metals and inhibiting the migration of metals in the soil-plant system. However, $\mathrm{Cu}$ and $\mathrm{Zn}$ are essential mineral elements for tobacco growth, and application of HA inhibits their uptake by tobacco, as previous studies observed [52]. Due to the limited complexing capacity of HA [26], the accumulation capacity of tobacco toward different metals varies. When soil has a high content of heavy metals (or has a high effective state content), tobacco still has a certain risk of $\mathrm{Cd}$ and $\mathrm{Pb}$ accumulation.

\section{Conclusions}

The addition of HA significantly reduced the available metal contents in the soil. The available $\mathrm{Cd}, \mathrm{Pb}, \mathrm{Cu}$, and $\mathrm{Zn}$ was inactivated by maximum percentages (HA14.8 $\mathrm{kg} \cdot \mathrm{ha}^{-1}$ ) of $37 \%, 39 \%, 18 \%$, and $29 \%$, respectively. The bioavailable fractions were transformed into nonbioavailable fractions more significantly upon applying HA. Tobacco had an accumulation effect toward $\mathrm{Cd}$, whereas it had only an absorption effect toward $\mathrm{Pb}, \mathrm{Cu}$, and $\mathrm{Zn}$. HA distinctly decreased the uptake of toxic elements such as $\mathrm{Cd}$ and $\mathrm{Pb}$ in tobacco leaves. It is worth noting that HA treatment also inhibited the uptake of mineral elements such as $\mathrm{Cu}$ and $\mathrm{Zn}$ into tobacco leaves. The metal contents in the upper, middle, and lower leaves were significantly reduced with HA treatment. However, the concentration of $\mathrm{Cd}$ in the modified soil far exceeded the standard limit of the Chinese environmental quality standard for soil (0.6 mg.kg-1, GB15618-2018), which means that this polluted soil would still not be suitable for agricultural use, even after the addition of HA.

Author Contributions: Conceptualization, Q.R. and C.Z.; methodology, H.H.; project administration, K.Z.; software, K.Z.; supervision, X.N.; validation, C.Z.; writing—original draft, Q.R.; writing—review and editing, C.L. All authors have read and agreed to the published version of the manuscript.

Funding: The study was supported by the National Natural Science Foundation of China (no. 41461091), the Natural Science Foundation of Guangxi, China (no. 2015GXNSFEA139001) and the College Young and Middle-aged Teachers' Basic Ability Improvement Project of Guangxi, China (no. KY2016YB038).

Conflicts of Interest: No potential conflict of interest was reported by the authors.

\section{References}

1. Zhao, F.J.; Ma, Y.; Zhu, Y.G.; Tang, Z.; Mcgrath, S.P. Soil contamination in china: Current status and mitigation strategies. Environ. Sci. Technol. 2015, 49, 750-759. [CrossRef] [PubMed]

2. Grant, C.A.; Bailey, L.D.; Mclaughlin, M.J.; Singh, B.R. Management Factors Which Influence Cadmium Concentrations in Crops; Springer: New York City, NY, USA, 1999.

3. Jia, Z.Y.; Wang, J.X.; Zhou, X.D.; Zhou, Y.J.; Li, Y.; Li, B.J.; Zhou, S.L. Identification of the sources and influencing factors of potentially toxic elements accumulation in the soil from a typical karst region in guangxi, southwest china. Environ. Pollut. 2020, 256, 113505. [CrossRef] 
4. Qu, S.Y.; Wu, W.H.; Nel, W.; Ji, J.F. The behavior of metals/metalloids during natural weathering: A systematic study of the mono-lithological watersheds in the upper pearl river basin, china. Sci. Total Environ. 2019, 134572. [CrossRef]

5. Lei, L.; Ma, Y.B.; Zhang, S.Z.; Wei, D.P.; Zhu, Y.G. An inventory of trace element inputs to agricultural soils in china. J. Environ. Manage. 2009, 90, 2524-2530.

6. Chen, H.P.; Yang, X.P.; Wang, P.; Wang, Z.X.; Li, M.; Zhao, F.J. Dietary cadmium intake from rice and vegetables and potential health risk: A case study in xiangtan, southern china. Sci. Total Environ. 2018, 639, 271-277. [CrossRef]

7. Gichner, T.; Patkova, Z.; Szakova, J.; Demnerova, K. Toxicity and DNA damage in tobacco and potato plants growing on soil polluted with heavy metals. Ecotoxicol. Environ. Saf. 2006, 65, 420-426. [CrossRef] [PubMed]

8. Daghan, H.; Uygur, V.; Koleli, N.; Arslan, M.; Eren, A. The effect of heavy metal treatments on uptake of nitrogen, phosphorus and potassium in transgenic and non-transgenic tobacco plants. Tarim Bilimleri Dergisi. 2013, 19, 129-139.

9. Maodzeka, A.; Hussain, N.; Wei, L.; Zvobgo, G.; Mapodzeke, J.M.; Adil, M.F.; Jabeen, S.; Wang, F.; Jiang, L.; Shamsi, I.H. Elucidating the physiological and biochemical responses of different tobacco (nicotiana tabacum) genotypes to lead toxicity. Environ. Toxicol. Chem. 2017, 36, 175-181. [CrossRef] [PubMed]

10. White, P.J.; Broadley, M.R. Biofortification of crops with seven mineral elements often lacking in human diets-Iron, zinc, copper, calcium, magnesium, selenium and iodine. New Phytologist. 2009, 182, 49-84. [CrossRef]

11. Xiu, F.; Fan, Y.K.; Xu, Z.C.; Zhang, S.; Wei, Z.Z.; Ren, Z.G. Research progress of zinc nutrition in tobacco. Chin. Agricul. Sci. Bullet. 2017, 33, 46-51.

12. Yang, B.; Zu, C.L.; Li, B.; Yao, Z.D.; Guo, D.F.; Jiang, C.Q.; Sheng, J. The influence of zinc and boron on tobacco growth and other mineral elements accumulation. Chin. Agricul. Sci. Bull. 2014, 30, 218-222.

13. Liu, P.; Zhang, Y.Y.; Wu, Y.H.; Gen, D.X.; Zhou, N.; Cao, Z. Effects of copper stress on nutrient uptake and physiological characteristics of tobacco root. J. Zhe jiang Norm. Univ. (Nat. Sci.). 2009, 32, 442-447. (In Chinese)

14. Hecht, S.S. Tobacco carcinogens, their biomarkers and tobacco-induced cancer. Nat. Rev. Cancer 2003, 3, 733-744. [CrossRef] [PubMed]

15. Babcsanyi, I.; Tamas, M.; Szatmari, J.; Hambek-Olah, B.; Farsang, A. Assessing the impacts of the main river and anthropogenic use on the degree of metal contamination of oxbow lake sediments (tisza river valley, hungary). J. Soils Sediments. 2019. [CrossRef]

16. Xiao, R.; Wang, P.; Mi, S.S.; Ali, A.; Liu, X.Y.; Li, Y.M.; Guan, W.D.; Li, R.H.; Zhang, Z.Q. Effects of crop straw and its derived biochar on the mobility and bioavailability in cd and $\mathrm{zn}$ in two smelter-contaminated alkaline soils. Ecotoxicol. Environ. Saf. 2019, 181, 155-163. [CrossRef] [PubMed]

17. Deng, H.; Ye, Z.H.; Wong, M.H. Accumulation of lead, zinc, copper and cadmium by 12 wetland plant species thriving in metal-contaminated sites in china. Environ. Pollut. 2004, 132, 29-40. [CrossRef] [PubMed]

18. Liu, H.; Zhang, Y.; Zhou, X.; You, X.; Shi, Y.; Xu, J. Source identification and spatial distribution of heavy metals in tobacco-growing soils in shandong province of china with multivariate and geostatistical analysis. Environ. Sci. Pollut. Res. 2017, 24, 5964-5975. [CrossRef]

19. Ivanova, R. Effect of chemical forms of lead, cadmium, and zinc in polluted soils on their uptake by tobacco. J. Plant Nutr. 2004, 27, 757-773.

20. Gruter, R.; Costerousse, B.; Bertoni, A.; Mayer, J.; Thonar, C.; Frossard, E.; Schulin, R.; Tandy, S. Green manure and long-term fertilization effects on soil zinc and cadmium availability and uptake by wheat (Triticum aestivum L.) at different growth stages. Sci. Total Environ. 2017, 599, 1330-1343. [CrossRef]

21. Kulikowska, D.; Gusiatin, Z.M.; Bulkowska, K.; Klik, B. Feasibility of using humic substances from compost to remove heavy metals $(\mathrm{cd}, \mathrm{cu}, \mathrm{ni}, \mathrm{pb}, \mathrm{zn})$ from contaminated soil aged for different periods of time. J. Hazard. Mater. 2015, 300, 882-891. [CrossRef]

22. Nagajyoti, P.C.; Lee, K.D.; Sreekanth, T.V.M. Heavy metals, occurrence and toxicity for plants: A review. Environ. Chem. Lett. 2010, 8, 199-216. [CrossRef]

23. Janos, P.; Vavrova, J.; Herzogova, L.; Pilarova, V. Effects of inorganic and organic amendments on the mobility (leachability) of heavy metals in contaminated soil: A sequential extraction study. Geoderma. 2010, 159, 335-341. [CrossRef]

24. Yang, T.; Hodson, M.E. Investigating the use of synthetic humic-like acid as a soil washing treatment for metal contaminated soil. Sci. Total Environ. 2019, 647, 290-300. [CrossRef] [PubMed] 
25. Zhou, H.; Meng, H.; Zhao, L.; Shen, Y.; Hou, Y.; Cheng, H.; Song, L. Effect of biochar and humic acid on the copper, lead, and cadmium passivation during composting. Bioresour. Technol. 2018, 258, 279-286. [CrossRef]

26. Gondar, D.; Lopez, R.; Fiol, S.; Antelo, J.M.; Arce, F. Cadmium, lead, and copper binding to humic acid and fulvic acid extracted from an ombrotrophic peat bog. Geoderma 2006, 135, 196-203. [CrossRef]

27. Senesi, N.; Loffredo, E.; Tabatabai, M.A.; Sparks, D.L.; Alamoodi, L.; Dick, W.A. Metal Ion Complexation by Soil Humic Substances. In Chemical Processes in Soils; University di bari: Bari, Italy, 2005; p. 563.

28. Garcia-Mina, J.M. Stability, solubility and maximum metal binding capacity in metal-humic complexes involving humic substances extracted from peat and organic compost. Org. Geochem. 2006, 37, 1960-1972. [CrossRef]

29. Xiong, J.; Koopal, L.K.; Tan, W.F.; Fang, L.C.; Wang, M.X.; Zhao, W.; Liu, F.; Zhang, J.; Weng, L.P. Lead binding to soil fulvic and humic acids: Nica-donnan modeling and xafs spectroscopy. Environ. Sci. Technol. 2013, 47, 11634-11642. [CrossRef]

30. Shi, R.Y.; Liu, Z.D.; Li, Y.; Jiang, T.M.; Xu, M.G.; Li, J.Y.; Xu, R.K. Mechanisms for increasing soil resistance to acidification by long-term manure application. Soil Tillage Res. 2019, 185, 77-84. [CrossRef]

31. Xi, J.H.; He, M.C.; Lin, C.Y. Adsorption of antimony $(\mathrm{V})$ on kaolinite as a function of $\mathrm{pH}$, ionic strength and humic acid. Environ. Earth Sci. 2010, 60, 715-722. [CrossRef]

32. Provenzano, M.R.; D'Orazio, V.; Jerzykiewicz, M.; Senesi, N. Fluorescence behaviour of zn and ni complexes of humic acids from different sources. Chemosphere. 2004, 55, 885-892. [CrossRef]

33. Bao, S.D. Soil Agro-Chemistrical Analysis (third edition); China Agriculture Press: Beijing, China, 2018. (In Chinese)

34. Baker, D.E.; Amacher, M.C. Nickel, copper, zinc, and cadmium. In Methods of Soil Analysis. Part. Chemical E Microbiological Properties; American Society of Agronomy: New York, NY, USA, 1982.

35. Tessier, A.; Campbell, P.; Bisson, M. Sequential extraction procedures speciation of particulate trace metals. Anal. Chem. 1979, 51, 844-851. [CrossRef]

36. Irving, H.; Williams, R.J.P. Order of stability of metal complexes. Nature 1948, 161, 436-437. [CrossRef]

37. Abate, G.; Masini, J.C. Acid-basic and complexation properties of a sedimentary humic acid. A study on the barra bonita reservoir of tiet(e)over-cap river, s(a)over-tildeo paulo state, brazil. J. Braz. Chem. Soc. 2001, 12, 109-116. [CrossRef]

38. Han, F.X.; Banin, A.; Kingery, W.L.; Triplett, G.B.; Zhou, L.X.; Zheng, S.J.; Ding, W.X. New approach to studies of heavy metal redistribution in soil. Adv. Environ. Res. 2003, 8, 113-120. [CrossRef]

39. Yu, Y.; Wan, Y.; Wang, Q.; Li, H. Effect of humic acid-based amendments with foliar application of zn and se on cd accumulation in tobacco. Ecotoxicol. Environ. Saf. 2017, 138, 286-291. [CrossRef]

40. Pandey, A.K.; Pandey, S.D.; Misra, V. Stability constants of metal-humic acid complexes and its role in environmental detoxification. Ecotoxicol. Environ. Saf. 2000, 47, 195-200. [CrossRef]

41. Zhang, S.; Song, J.; Cheng, Y.W.; Liu, G.; Wallace, A.R. Trace metal(loid)s exposure through soil-tobacco-human pathway: Availability in metal-contaminated agricultural soils, transfer models and health risk assessment. Ecotoxicol. Environ. Saf. 2018, 148, 1034-1041. [CrossRef]

42. Spark, K.M.; Wells, J.D.; Johnson, B.B. The interaction of a humic acid with heavy metals. Soil Res. 1997, 35, 89-101. [CrossRef]

43. Zhang, Y.; Yang, X.; Zhang, S.; Tian, Y.; Guo, W.; Wang, J. The influence of humic acids on the accumulation of lead $(\mathrm{pb})$ and cadmium (cd) in tobacco leaves grown in different soils. J. Soil Sci. Plant Nutr. 2013, 13, 43-53.

44. Lin, B.S.; Gao, H.J.; Lai, H.M.; Li, C.H.; Wang, Q. Characterization of heavy metals in soils from typical tobacco cultivated areas, china. Environ. Prog. Sustainable Energy. 2016, 36, 483-488. [CrossRef]

45. Nikolov, N.; Bozhinova, R.; Hristeva, T.S. Reducing the accumulation of pb, cd, zn and cu in tobacco, grown on an acidic soil (planosol), using black sea sapropels. J. Environ. Prot. Ecol. 2016, 17, 146-153.

46. Dong, S.F.; Yang, X.; Luo, H.Y.; Zhu, H.B.; Wang, J.H.; Yan, H.; Ming, N.I.; Ou yang, J.; Liu, H.G.; Rao, Z. Study on different absorption ability of clue-cured tobacco varieties to six kinds of heavy metals. J. Zhengzhou Univ. Light Ind. Nat Sci. 2014, 29, 32-38. (In Chinese)

47. Hong, L.; Mei, Y.F.; Guo, Y.Q.; Li, J.; Lin, Y.H. Effect of potassium fertilizer on cadmium residue in tobacco leaf. Southwest China J. Agric. Sci. 2016, 29, 352-359. (In Chinese)

48. Wei, Y. Study of Lead, Cadmium and Tobacco Field Type of Relationship of Differenct Flue-Cure Tobacco Varieties Accumulations. Master's Thesis, Hunan Agricultural University, Changsha, China, 2013. (In Chinese). 
49. Liu, J.; Wei, H.E.; Zhou, J.H.; Yang, Z.Y.; Zhang, F.M.; Yang, H.Q.; Xiao, Z.X.; Wang, L. Response ability of flue-cured tobacco varieties to soil micro-nutrients. Chinese Tobacco Sci. 2010, 31, 37-40. (In Chinese)

50. Jiang, L.L. "Thirteen domestic cigarettes have been reported heavy metals excessive -the tobacco institute said" not exactly". Commod. Qual. 2010, 51, 16.

51. Wei, Y. Tobacco production of china contains three times more heacy metals than foreign tobacco production. Living Sci. 2011, 01, 50.

52. Wu, S.G.; Bai, H.Y.; Zhang, C.L.; Wei, J.Y.; Zeng, X.N.; Jiang, D.H.; Chen, P.Q. Study on the effect of potassium fertilizer and the nutrtion regulator on the contents of potassium and the heavy metals in flue-Cured tobacco leaves. Chin. J. Soil Sci. 2012, 43, 196-200. (In Chinese)

(C) 2020 by the authors. Licensee MDPI, Basel, Switzerland. This article is an open access article distributed under the terms and conditions of the Creative Commons Attribution (CC BY) license (http://creativecommons.org/licenses/by/4.0/). 